\title{
Strategies of Translation in Live Metaphors in Sumatera Folklores Into English
}

\author{
Lucy Khawardi \\ English Applied Linguistics Study \\ Program \\ Universitas Negeri Medan \\ North Sumatera, Indonesia \\ lucykhawardi88@gmail.com
}

\author{
Anni Holila Pulungan \\ English Applied Linguistics Study \\ Program \\ Universitas Negeri Medan \\ North Sumatera, Indonesia
}

\author{
Amrin Saragih \\ English Applied Linguistics Study \\ Program \\ Universitas Negeri Medan \\ North Sumatera, Indonesia
}

\begin{abstract}
This study investigated the strategies of translation in live metaphors in Sumatera folklores into English. This study was conducted to describe the strategies applied in the translation live metaphors in the Sumatera folklores. This study was conducted by using qualitative design. The data were the utterances of live metaphor in Sumatera folklores. The findings showed that there were strategies in translating live metaphors was proposed by Larson's theory. Language has special characteristic that is live metaphors phrases, therefore in the case of translating the metaphor phrases in which their concept in unknown for readers, the translator often faces the problem to translate a live metaphor from a source language (SL) into a target language (TL).
\end{abstract}

Keywords - Translation Strategies, Live Metaphor, Sumatera Folklores

\section{INTRODUCTION}

Folklores, folktales, novels and so on have always been one of the subjects of translation. Translation becomes the bridge linking a folklore with the readers who do not speak the language which the folklore is written in. Literary translation is translation of literary works such as short stories, novels, poems, play, and etc. It has special characteristics as literary works different from non-literary works. Larson defined translation as The process of transferring the meaning of the source language into the receptor language. This is done by going from the form of the first language to the form of a second language by way of semantic structure. It is meaning which is being transferred and must be held constant[1].

Figurative language is used in any form of communication, such as in daily conversation, articles in newspaper, advertisements, novel, poemn, etc. This study will discussing about one of kind of figurative language namely metaphor. Metaphor is considered by linguist as the most basic where one object is used to describe another object and both objects are essentially disparate entities, but common in one or more attributes (Encarta Dictionary). In other words, metaphor is use of a word or a phrase for the purpose of suggesting a likeness between the two. In the folklores writer find a phenomenon of language such as figurative language especially the figure of the comparison namely metaphor. Metaphors are often become the problem of the translator, and may occur at all levels from word to text at which level it becomes an allegory or fantasy. In accordance with translation, the metaphors must be translated very carefully in order to avoid misunderstanding. Larson states that If metaphors from source language are translated literally into the target language, they will often be completely misunderstood. Because the translation cannot simply reproduce, or be, the original. In fact, in the folklores there are still literally in translating the text.

These facts indicated that there is another strategies in translation that used by the translator when translating Indonesian metaphors into English besides using strategies from Newmark in order to avoid misunderstanding because of using literal translation or word for word strategy. And based on the phenomenon above, then the researcher become interesting to identify the strategies of translating live metaphor in Folklores from Indonesian into English[2]. Larson"s theory was used to analyze the strategies of translation live metaphors in the folklores, the realization and the reason of the realization translation strategies in the folklores.

\section{THEORETICAL BACKGROUND}

\section{A. Theory of Translation Strategies}

In our understanding, translation is a process of transferring the meaning of the source language into the target language. Every translator expert has some different versions about the definition of translation. Catford states that translation is the replacement of textual material in one language (SL) by equivalent textual material in another language (TL) [3]. Catford explains that translation is not only about transferring language but also find the equivalent of the results of translation, the equivalent itself can be defined such as the culture, situation, actual word choices, etc. Those aspects are really important in translation, because every language has different culture and situation, that is why the translator should find the appropriate word to translate the source text into the target text so that the reader can 
understands the text not as a translated text but as a source text (as natural as their language).

The word translation is defined either as a process (Meaning 1) or a product (Meaning 2) as it is described:

e.g. translation, $n$.

1. The act or an instance of translating.

2. A written or spoken expression of the meaning of a word, speech, book etc in another language. (The Concise Oxford Dictionary)

It means that the process of translation goes beyond the simple concept of merely replacing words in one language with words in another. And Hatim and Munday explain these two dictionary definitions or views of translation well [4]. Translation as a process based on Hatim and Munday interpretation refers to the role of the translator in taking the original or ST and turning it into a text in another language, the target text TT. Translation as a product "centers on the concrete translation product produced by the translator" Hatim and Munday.

Larson"s point of view in her book "Meaning-based Translation" for translating metaphors and simile are almost similar. There are five strategies in tranlating a metaphor, they are:

1. The metaphor may be kept if the receptor language permits. The first step is to determine whether the comparison is a "live" metaphor or simile, or whether it is simply a "dead" figure. If the words which are figurative are simply a dead metaphor, then the image does not need to be kept, but the meaning can be translated directly, if it sounds natural and understood correctly by the readers. Example, large rotten fish were laid on handsome silver platters.

2. However, if the comparison is a live metaphor then the translator should analyze the metaphor carefully. It can be very helpful to write down explicitly the two propositions with the topic, the image, and the point of similarity. In the case of metaphors, it is possible sometimes to keep the metaphorical image. In some languages, it would be much clearer if the metaphor was changed to a simile. Similes are more easily understood than metaphors in most languages. For example, the road is a snake, snake means something like crooked. It would be much clearer if the metaphor was changed to a simile and the sentence was 'the road is like a snake'.

3. A metaphor or the receptor language which has the same meaning may be substituted as long as the nonfigurative meaning of the metaphor is not lost or distorted. For example, there was a storm in parliament.It might be good in some languages to change the metaphor from storm to fire, and the translation would read, the parliament was on fire last night $^{\text {ee }}$.

4. The translator might keep the metaphor of the source text and also explain the meaning, that is the topic and/or point of similarity may be added, so as not to lose the intended force of the metaphor. For example: 'the tongue is a fire'. It might be translated into 'the tongue is a fire'. A fire destroys things, and what we say can ruin people.

5. There will be some times when the translator will simply need to ignore the image in the source text. The meaning of the metaphor may be translated without keeping the metaphorical imagery. For example: 'he was a pig' might simply be translated 'he is a messy person'.

\section{B. Live Methapor}

Live metaphors are those which are contructed on the spot by the author or writer to teach or illustrate. It is one which is understood only after paying special attention to the comparison which is being made. A characteristic of a live metaphor can be described as a comparison that shows how two things that are not alike in most ways are similar in another important way. In daily life, when you portray a person, place, thing, or an action as being something else, even though it is not actually that "something else," you are speaking metaphorically. For example, the phrase, "My brother is the black sheep of the family," is a live metaphor because he is not a sheep, nor is he black. However, we can use this comparison to describe an association of a black sheep with that person. A black sheep is an unusual animal, which typically stays away from the herd, and the person being described shares similar characteristics. Guttenplan proposes that a live metaphor is one that requires effort to interpret it, while dead metaphors, which are entered into dictionaries, require no effort[5]. What makes them nonetheless metaphors is that a context is imaginable in which their interpretation would require more effort.Additional examples of live metaphors are below:

\section{1. „The assignment was a breeze ${ }^{e e}$. (This implies that} the assignment was not difficult).

2. „Her voice is music to his ears ${ }^{\text {ee }}$. (This implies that her voice makes him feel happy).

3. ,My brother was boiling mad ${ }^{\text {ee }}$. (This implies that he was too angry).

There is also a characteristic of live metaphor is marked by the existence of comparability or similarity between tenors and rides that are perceptual, vague, or cultural[6]. With these characteristics it appears that the live metaphor still does not freeze, but still fresh and creative.Live metaphors function as part of productive networks in which wedraw extensions like 
these from antecedent metaphors, thus situatingthe given metaphor in a web of expressions.

\section{SUMATERA FOLKLORES}

Cerita rakyat is a form of folklore found in Indonesia. Their origins are probably an oral culture, with a range of stories of heroes associated with Wayang and other forms of theatre, transmitted outside of a written culture and usually tied in with a district or region of Indonesia, Sumatera folklore reflect the diverse culture of Indonesia as well as the diversity of ethnic groups in Indonesia [7]. Many ethnic groupshave their collection of tales and folklores being told for generations. The stories usually told to children as some kind of bed-timestory, and have pedagogical value on kindness, benevolence, modesty, honesty, bravery, patience, persistence, virtue and morality.

For example, the popular theme is "the truth is always prevail, the evil will always defeated". While most of Indonesian children folklore stories have happy ending plots and a 'happily ever after' theme, some employ tragedyand have rather sad endings.Most of Sumatera folklore started as oral tradition; being told by story teller or parents for generations within Indonesian villages. The story were often sung or chanted in several oral traditions such as pantun, tembang, or children chants. Some are beingperformed in performing arts such as wayang and sendratari (dance drama).

Sumatera has ten provinces such as Aceh, Bengkulu, Jambi, Lampung, Riau, Bangka Belitung, Kepulauan Riau, West Sumatera, South Sumatera, and North Sumatera.Every region in Indonesia has a variety of folklore. For the people of Aceh, folklore is a valuable cultural treasure, inherited from generation to generation, able to play a role in fostering understanding, meaning of inheritance, cultural treasures, nurturing and expanding the imagination to enjoy it. As a cultural richness, folklore is the result of the thinking of the social and cultural system of the local community which is the embodiment of expression that reflects the cultural elements of a society. One of the famous folklore is Mentiko Beutuah. The important role of folklore in an area lies in its ability to communicate traditions, knowledge, customs, or describe human experiences in both individual dimensions and social dimensions.

\section{PRESENT STUDY}

This paper is concerned with strategies in translatio of live metaphors in Sumatera Folklores into English.. And the results from the present study, most of which has found that the translator still use literally translation when translating the text. And also investigates the strategies of translation that was applied in translating the live metaphors in Sumatera Folklores.

\section{METHOD - PARTICIPANTS, INSTRUMENT}

To find plausible answers to the research questions, researcher used qualitative method and was designed in which a number of requests were collected from a sample of
Sumatera Folklores. Descriptive research is designed to obtain information concerning the current status phenomena. In qualitative research, there is little or no statistic. Totally there are 15 folklores from the whole of Sumatera. The instrument for collecting the data were documentary sheet.

\section{FINDING AND DISCUSSION}

\section{A. Data Result}

After analyzing the data, it was found that there were four strategies applied by the translator in translating the live metaphors in the Sumatera Folklores from source language into target language, namely; 1) translating the metaphors into simile $(14,28 \%), 2)$ keeping the metaphorical image $(77,55 \%)$, 3 ) substituting metaphor of the receptor language which has the meaning $(6,12 \%), 4)$ translating into simile plus sense $(2,04)$. The strategies which was not found in translating live metaphor by the translator was translating into metaphor and explain the meaning and translating the meaning of the metaphor without keeping the metaphorical image.

\section{B. Discussion}

Sudrama identifies three strategies of translating the live metaphors in his study, namely; translating metaphor into metaphor, translating metaphor into simile and translating metaphor without keeping the metaphorical image [8]. While, in this study there were three strategis by larson and one strategy that is not mentioned by the other researcher above. This strategy is not a part of Larson strategies, but it was used by the translator when translating the live metaphors in the Sumatera Folklores into English. By seeing the percentage, it can be seen that the strategies of translating by keeping metaphorical image was dominant strategy.

\section{CONCLUSION}

After analyzing the data collected from Sumatera Folklores, the reseacher now can draw a conclusion as follow: there are some strategies of translating live metaphors such as keeping metaphorical image, translating into simile, substituting metaphor of the receptor language which has the same meaning, and translating into simile plus sense and the dominant strategy that used in the folklores was translating by keeping metaphorical image.

\section{References}

[1] Larson, M. L. (1998). Meaning-Based Translation: A Guide to Cross Language Equivalence. Lanham and London: University Press of America.J. Clerk Maxwell, A Treatise on Electricity and Magnetism, 3rd ed., vol. 2. Oxford: Clarendon, 1892, pp.68-73.

[2] Newmark, P. (1988). A Textbook of Translation. London \& New York: Prentice Hall.K. Elissa, "Title of paper if known," unpublished.

[3] Catford, J. C. (1974). A Linguistic Theory of Translation. London: Oxford University Press.

[4] Hatim, B. And J. Munday. (2004). Translation: An Advanced Resource Book. Guildford, UK.

[5] Guttenplan, S. (2005). Objects of Metaphor. Oxford: Oxford University Press. 
[6] Subroto, E. (2010). Pengantar Metoda Penelitian Linguistik Struktural. Surakarta: Sebelas Maret University Press.

[7] Awang, H. (2005). Sastera Rakyat. Yogyakarta: GPFE
[8] Sudrama, K. (2003). Strategies for Translating into Indonesian English Metaphors in the Novel Master of the Game: A Case Study. Thesis. Denpasar: Udayana University. 